CZASOPISMO INŻYNIERII LA¿DOWEJ, ŚRODOWISKA I ARCHITEKTURY JOURNAL OF CIVIL ENGINEERING, ENVIRONMENT AND ARCHITECTURE

JCEEA, t. XXXIII, z. 63 (1/II/16), styczeń-marzec 2016, s. 367-374

Tomasz SZCZURASZEK

Radosław KLUSEK ${ }^{2}$

Grzegorz BEBYN $^{3}$

\title{
ENHANCEMENT OF ROAD SAFETY THROUGH MORE EFFECTIVE ROAD AND TRAFFIC MANAGEMENT
}

\begin{abstract}
To make the policy aimed at mitigating the risk of road incidents more effective, Poland should see the introduction of the more efficient road and traffic management. In November 2008 the European Parliament and the European Council published the Directive on "infrastructure safety management" which provides guidance on the procedures for carrying impact assessments of traffic safety, traffic safety audits, safety management on the road network and monitoring traffic safety in Member States. In this article, the authors have proposed a systemic approach to road and traffic management, involving the implementation of consistent procedures that should include regular revisions of roads, eliminating hazardous sites, speed management, as well as the approval and implementation of traffic organization designs.
\end{abstract}

Keywords: road safety, traffic, traffic management

\section{Introduction}

The level of hazards on roads is closely related to the road environment. According to research [1], a cause or concurrent cause of $65 \%$ road incidents included a road and its surrounding. We can influence the technical and operational characteristics of roads both in the process of creating road infrastructure and during its operation. The analyses conducted in the Kujawsko-Pomorskie Voivodeship reveal that numerous mistakes are committed both at the stage of planning and designing roads. Such errors are very difficult to eliminate dur-

\footnotetext{
${ }^{1}$ Autor do korespondencji/corresponding author: Tomasz Szczuraszek, University of Science and Technology, Department of Road and Transport Engineering, ul Kaliskiego 7, 85-796 Bydgoszcz, tel. (52) 340-84-30, zikwb@utp.edu.pl

${ }^{2}$ Radosław Klusek, University of Science and Technology, Department of Road and Transport Engineering, radosław.klusek@utp.edu.pl

${ }^{3}$ Grzegorz Bebyn, University of Science and Technology, Department of Road and Transport Engineering, bebyng@utp.edu.pl
} 
ing the use of a road network; hence, the maintenance of the desired road safety level at the stage of its operation is very difficult.

The authors have used the example of the Kujawsko-Pomorskie Voivodeship to formulate in the road safety diagnosis a number of critical comments on the management of roads and traffic. Such reservations concern mostly the omission or improper performance of great many procedures by the considerable majority of road and traffic administrators. However, such procedures are necessary and essential to the maintenance of the required road safety level in the road network. An important role is played by the shortage of suitable tools that might facilitate the implementation of a correct policy of road and traffic management in almost all organizations concerned. The lack of a suitably equipped and maintained IT database arouses serious concerns in this respect.

The Directive of the European Parliament and the European Council number 2008/96 of 19 November 2008 concerning the "infrastructure safety management" provides detailed guidance on the procedures for carrying out impact assessments of road safety, road safety audits, safety management and monitoring on road network in the Member States.

To adjust to the Directive in this article, some systemic solutions have been proposed that may eliminate the most common irregularities and faults. The idea of enhancing road safety has been based on the implementation of the following permanent tasks in the process of road and traffic management (see Figure 1):

- conducting regular revisions of roads in terms of operational standards and road safety;

- the implementation of the process of liquidating hazardous spots;

- the implementation of the vehicle speed management process in the road network; and

- the introduction of the amended procedure of approving and implementing traffic organization projects.

\section{The implementation of systemic road revisions in terms of compliance with operational and road safety standards}

One of the essential tasks related to road and traffic management is the maintenance of infrastructural elements that provide safety and operational standards. To enable the control of such road elements and equipment, road administrators have to carry out regular revisions of roads and remove successively any found irregularities that do not conform to the required standards.

In Poland, the obligation to carry our regular road revisions stems from the European Directive No. 2008/96 of the European Parliament, changes to the law of Public Roads of 13 April 2012 (Journal of Laws No. 2012, Item 472) and 


\section{IMIPROVEMENT OF ROAD SAFETY OWING TO THE EFFECTIVE ROAD AND} TRAFFIC MLANAGEMENT

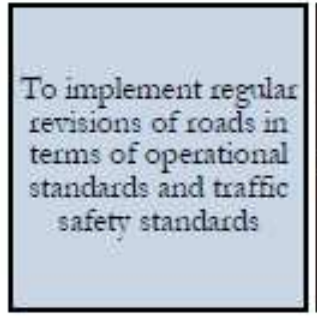
To derelop ausiliart materials for compliant and effective road revisions

To introduce regular road inspections and observations in-situ

To introduce the
regular preparation
of road revision
reports

To introduce regular
actions related to the
performance of
maintenance work
and the attainment of
a suitable road safety
level

To provide road management with equipment necessart for road inspections. detailed

observations, and studies in situ

The establishment of the central database that enables the more effective management of roads and traffic

Fig. 1. Schema of necessary actions that enable the improvement of road safety through the efficient road and traffic management in the area of the voivodeship

Rys. 1. Schemat zakresu niezbędnych działań umożliwiających poprawę bezpieczeństwa ruchu drogowego poprzez efektywniejsze zarządzania drogami I ruchem drogowym na obszarze województwa 
Regulation by the Minister of Infrastructure of 23 September 2003 on special conditions of managing road traffic and the supervision over such activities (Journal of Laws No. 177, Item 1729). §12(5) of the Regulation imposes the duty on a traffic manager to carry out inspections of the compliant application, performance, operation, and maintenance of all road signs, traffic light devices, traffic sound devices, and traffic safety devices located on roads minimum every six months. The Act on public roads also obliges road administrators to carry out regular controls of road and road engineering facilities on a regular basis, in particular in terms of their impact on road safety (Journal of Laws No. 14, Item 60, as amended). The present experience indicates [1,3] that except for national roads, there are no revisions in voivodeships and, if they do occur, they are not always carried out properly. The procedure proposed by the authors enables the comprehensive and more exact revision of roads. Its idea is based on the creation of tools that enable managers the correct fulfilment of tasks related to the maintenance of road infrastructure, including by determining the procedures, solutions to be applied, and methods of introducing the effective observations insitu. A new element of the proposed procedure is the inclusion of the regular assessment of roads used by children to come to school, mostly in terms of their safety. The main objective of such actions is to determine in advance (before a road incident takes place that involves children) any spots that are hazardous for children, considering their psychophysical limitations and difficulties in road traffic and, as a consequence, the application of relevant remedial measures that would provide such locations with the safety level acceptable for the children [2].

In order to implement the procedure of road operation condition controls, auxiliary materials are to be developed for the proper and effective revisions of roads, which will detail the scope and describe the procedures of conducting regular inspections. A database is also to be established in individual road management agencies, to facilitate road and traffic management. Local databases are to be compatible with the databases of 'Road book' and 'Bridge facility book' (according to the Journal of Laws No. 32, Item 393, a road administrator is obliged to keep a record of roads and bridge facilities). Every revision should result in a report. If any non-conformities are found in the report or any violations of required technical standards in a road element, measures are to be taken to enable the performance of maintenance work in order to achieve the required road safety level in the road network.

\section{Implementing the process of eliminating hazardous spots in the road network}

In practice, poviat road administration, gmina offices, and municipal administrations of small towns in Poland are not involved in the process of eliminating hazardous spots. On the other hand, most other road administrators do implement some individual policies of eliminating hazardous spots; however, 
they are generally not proper and do not bring the expected effects. The reconstructions, developments, and changes of traffic organization as well as other repair work aimed at enhancing road safety at a specific location in a road network are not carried out systematically; they are often conducted at random, during other investment projects, or after obtaining special funds for increasing road safety from the domestic or EU funds. A proposal of eliminating hazardous spots made by the authors involves the creation of suitable tools and facilities for road administrators to fulfil regular tasks within the search for such spots in their road network, to conduct their detailed assessments, and to perform planned remedial work in-situ, including the monitoring of its effects. Likewise in the case of inspections, when eliminating hazardous spots a database should be created that will enable road administrators to collect any information on the ongoing basis, as necessary in the process of eliminating hazardous spots. The road administration should have a suitable computer station with necessary software. Moreover, auxiliary materials are to be developed for the analyses of road safety and to select solutions used to improve road safety.

\section{The implementation of the vehicle speed management process in the road network}

Today, it is commonly known that one of the most effective methods of enhancing road safety is speed management. However, most voivodeships do not implement a conscious or reasonable speed management policy, even on national roads [1]. Many road administrators identify speed management mostly with speed controls conducted by the police or by municipal, poviat or gmina traffic wardens. Therefore, most of them are not aware of the present speed of vehicles in their network or, obviously, hazards that may be caused by such speed. Even such important actions as determining speed limits in a road network are taken by many road administrators incorrectly, because setting speed limits does not result from detailed road safety analyses or a specific hazard in traffic, but from incidental and interventional actions following a road accident or due to social pressure. The introduction of traffic calming zones is among the exceptional and very rare planned activities related to speed management.

Speed management proposed by the authors involves the conscious development of vehicle speeds on a road so that a relatively high level of road safety is accompanied by the desired operational level, i.e. the service of road network users and the economic efficiency of transport of people and goods. The point is that while managing roads and traffic a compromise should be sought between safety and the speed of travel (including traveling time). After all, the increase of speed without the proper protective actions will always lead to the higher risk of road accidents and the number of fatalities, although it will result in shorter travel times. Therefore, such a compromise involves primarily the maintenance of the given (pre-determined) operational speeds of vehicles with the acceptable 
road safety level, which means the safety level for which the probability of a road accident is relatively low. Therefore, in this case the suitable speed management by a road administrator should involve monitoring maximum operational speeds of vehicles on every element of his road network. If a road administrator finds safe speeds exceeded on any elements of the network, he should take suitable actions that will lead to the fulfilment of this condition [2].

To achieve the proper vehicle speed management, it is necessary to develop auxiliary materials that will include rules of conducting the studies of speed, visibility, and other road characteristics and providing the following methods:

- determining a safe speed;

- setting safe distances between vehicles in a traffic flow;

- determining safe differences between vehicle speeds in consecutive and adjacent road sections;

- estimating operational vehicle speeds; and

- determining uniform road sections or elements in terms of their traffic conditions.

Developing ready vehicle speed management manuals would enable road managers to set safe speed limits and would standardise speed limits on roads depending on their technical and operational characteristics.

\section{Introducing the changed procedure of approving and implementing designs of permanent and temporary traffic organization}

The enhancement of road traffic organization is among the most important tasks that is necessary to increase road safety. If traffic organization is defective, it may raise the risk of accidents and the severance of their effects significantly; on the other hand, if implemented optimally, it may reduce the hazard level substantially. Owing to the traffic organization that is well-thought-out, major errors of an intersection geometry or another element in a road network may be mitigated in terms of road safety. It is generally accepted that the remedy of such errors directly is usually costly and troublesome.

The diagnosis of work performed by traffic administrators in the KujawskoPomorskie Voivodeship has led to the conclusion that there are numerous irregularities in the procedure of approving and implementing traffic organization designs. The basic shortcomings of such designs include [1]:

- low qualifications of many a person approving traffic organization designs, in particular on the level of poviat and gmina roads;

- no road safety audits of all traffic organization designs (other than national roads within the European route corridors);

- no verification of the impact of the proposed traffic organization on the traffic safety; 
- the failure to implement fully approved designs of temporal traffic organization, in order to reduce construction costs, which leads to traffic disruptions and poses major hazards in traffic;

- neglecting commonly the safety of unprotected road users when implementing and approving designs of temporary traffic organization;

- the lack of suitable regulations and laws concerning detailed rules of conducting work on a roadway as well as catalogues of solution examples;

- in many cases (especially in cities) there is no adequate coordination of roadway occupation, which leads to major obstructions of traffic and serious hazards;

- the common lack of proper supervision over traffic organization in the course of roadwork;

- non-compliances of traffic organization solutions adopted in a design to applicable regulations;

- the fact that most road administrators do not have databases of traffic organization or suitable software, despite the statutory obligation to keep such records.

To address the above-mentioned deficiencies, the fulfilment of the following tasks is proposed:

1. the continual education of personnel involved in traffic organization, in particular persons who approve traffic organization designs as well as controlling the traffic organization status, both during and after work in a roadway;

2. the obligation to endorse traffic organization designs by a road safety auditor before their acceptance by a traffic administrator and a road administration;

3. the necessity to introduce traffic organization designs into a construction design, which will guarantee that traffic organization designs are prepared by persons holding required design qualifications;

4. the obligation to consult traffic organization designs with the authority that manages public transport, because an introduced traffic organization may change the operation of public transport;

5. the application of a changed procedure of approving traffic organization designs by traffic and road administrators and monitoring a traffic organization status during and after work, to provide the correct performance of traffic organization and the higher level of safety on a road; and

6. developing auxiliary materials that include examples of temporary traffic organization solutions. 


\section{Literature}

[1] Szczuraszek T. (edited by, collective work); Gambit Kujawsko-Pomorski Volume I: Diagnoza Bezpieczeństwa Ruchu Drogowego, DIAMOND BOOKS, Bydgoszcz 2010.

[2] Szczuraszek T. (edited by, collective work); Gambit Kujawsko-Pomorski Volume II: Program Poprawy Bezpieczeństwa Ruchu Drogowego w Województwie KujawskoPomorskim, DIAMOND BOOKS, Bydgoszcz 2012.

[3] Jamroz K., Budzyński M., Gaca S., et al.: GAMBIT Drogi Krajowe - Program bezpieczeństwa ruchu drogowego dla dróg krajowych w Polsce na lata 2007-2013, Fundacja Rozwoju Inżynierii Lądowej, Politechnika Gdańska, Politechnika Krakowska, Gdańska 2008.

[4] European Road Safety Observatory. Report Safety Net - www.erso.net 2005.

[5] The European Parliament and the European Council Directive no. 2008/96 on "infrastructure safety management".

\section{POPRAWA BEZPIECZENSTWA RUCHU DROGOWEGO POPRZEZ EFEKTYWNIEJSZE ZARZĄDZANIE DROGAMI I RUCHEM DROGOWYM}

Streszczenie

Aby polityka związana ze zmniejszaniem ryzyka zdarzenia drogowego była skuteczna należy w Polsce prowadzić bardziej efektywne zarzadzanie drogami oraz ruchem drogowym. W artykule autorzy zaproponowali systemowe podejście do zarządzania drogami i ruchem drogowym polegające na wdrożeniu stałych procedur systematycznego przeglądu dróg, likwidacji miejsc niebezpiecznych, zarządzania prędkością oraz zatwierdzania i wdrażania projektów organizacji ruchu.

Słowa kluczowe: bezpieczeństwo ruchu, ruch drogowy, zarządzanie ruchem

Przestano do redakcji: 07.06.2016 $r$.

Przyjęto do druku: 30.06.2016r.

DOI: $10.7862 / r b .2016 .96$ 